\title{
Washington dissensus: ambiguity and conflict at the International Monetary Fund
}

\author{
Tod S. Van Gunten* \\ Max Planck Institute for the Study of Societies, Cologne, Germany \\ *Correspondence: tvg@mpifg.de
}

\begin{abstract}
During the 1990s, the International Monetary Fund failed to develop clear exchange rate policy norms for developing countries, despite the fact that oversight of the international monetary system is central to its mandate. Explaining this behaviour requires revising theories of autonomous agenda-setting and 'ceremonial conformity' in international organizations (IOs). I argue that IOs often adopt a posture of strategic ambiguity when confronted with a combination of divisions among major member states and a lack of consensus in the profession that provides the organization's source of expert legitimacy. However, while the ambiguity helps avoid conflict in the short run, it undermines organizational governance capacity in the medium run, resulting in coordination failures. The empirical analysis relies on internal records of Fund meetings on the exchange rate issue, interviews with former IMF officials and analysis of the organization's governance role during currency crises in Mexico, Russia, Brazil and Argentina.
\end{abstract}

Key words: international economic order, global economy, financial crisis, developing countries, organizational theory

JEL classification: F5 International Relations and International Political Economy

The International Monetary Fund received extensive criticism for its role in the emerging market financial crises of the late 1990s and early 2000s (e.g. Wade and Veneroso, 1998; Stiglitz, 2003). However, despite considerable research and policy debate, one crucial area of the Fund's involvement in these crises remains poorly understood: the IMF's governance of exchange rate regimes in developing countries. Given that collapsing currency regimes were central to these crises, this is a significant omission. Observers have pointed out weaknesses in the governance of exchange rate regimes; the Fund's own Independent Evaluation Office found that the IMF's oversight 'was simply not as effective as it needs to be' (Independent Evaluation Office, 2007; c.f. Mussa, 2007). Yet while observers have described these failures, political and organizational analysts have not explained them. 
As this article shows, the IMF failed to develop clear norms governing exchange rate regimes in developing countries during the 1990s, despite the fact that overseeing exchange rate policies is at the core of its mandate. Indeed, governance of exchange rates was one of the founding goals of the IMF; it is, therefore, puzzling that the Fund failed to develop clear policies in an area so central to its mission. While the Fund's leadership attempted to clarify policy norms in the latter part of the decade, this effort foundered. This article shows that the Fund's failure to develop coherent policy norms in this area can be traced to the combination of divisions among powerful member states (in particular between the USA and Europe) and internal debates rooted in the economics profession. This case thus suggests revisions to theories advanced by principal-agent (PA) and organizational approaches to international organizations (IOs). First, some scholars have argued that divisions among major member states increase the autonomy of international financial institutions (IFIs) (Chwieroth, 2010; Copelovitch, 2010a; Martin, 2006). Second, others have argued that IOs respond to 'conflicting demands' by decoupling policy from practice, described by some as 'organized hypocrisy' (Weaver, 2008). In contrast, I argue that divisions among powerful member states-particularly when coupled with a weak claim to professional consensus - create a strong incentive for organizations to avoid contested issues through strategic ambiguity.

The logic underlying this argument is simple. IFIs' major shareholders share broad goalssuch as maintaining the stability of the international financial system and enforcing discipline in client states-but sometimes disagree over the policies best suited to achieving these goals. When this occurs, IOs have difficulty satisfying one member state without affronting another. As a result, divisions among shareholders create an incentive to avoid contested policy issues. Because IFIs legitimate their policies by claiming expertise, this pressure is greatest when the organization itself lacks a strong claim to authority rooted in professional consensus. One means of avoiding conflict in this scenario is strategic ambiguity, or the deliberate lack of clarity on a particular policy issue. However, while strategic ambiguity can minimize conflict in the short run, it undermines organizations' capacity to fulfil their mandates over the medium term. Because of this, ambiguity is an unstable strategy and is likely to be punctuated by attempts to clarify policy norms. However, without a strong claim to professional authority, norm development is likely to result in inconsistent and ineffective organizational behaviour. Moreover, if member states are unwilling to subordinate their policy preference to broader objectives, compromise norms run the risk of an explicit veto by a coalition of shareholders. Divisions among principals can therefore result in coordination failures rather than autonomy or 'organized hypocrisy'.

This framework helps account for the shifting behaviour of the IMF in the exchange rate policy domain. During most of the 1990s, the IMF avoided stating a clear policy on exchange rate regimes, instead practising strategic ambiguity in order to limit conflict among its principals, given that professional debate made it difficult for the staff to legitimately claim expert authority. However, this ambiguity limited the Fund's capacity to govern client states, weakening its leverage over several countries that ultimately experienced major currency crises. In response to both internal and external demands for clarity in the wake of these crises, IMF managers formulated a relatively clear exchange rate policy norm for developing countries, the so-called bipolar view. This norm stated that most developing countries must choose between freely floating and firmly fixed currencies, ruling out the 'intermediate' options that many countries adopted in practice. Yet while the bipolar view was a relatively clear norm, its basis in professional knowledge was weak, leading the Fund to behave inconsistently 
and ineffectively. Moreover, this proposed norm failed to overcome divisions among the IMF's major shareholders, ending in stalemate.

The article develops this argument by analysing the IMF's approach to the exchange rate issue in developing countries over the course of the 1990s. After developing the theoretical framework and situating it relative to previous approaches, I briefly review the context surrounding exchange rate policy and the debates that prevailed in the economics profession. Then, relying on internal IMF documents, I examine episodes in 1990 and 1999 during which the Fund's Executive Board (the organization's permanent governance body) debated exchange rate norms for developing countries. These meetings provide a window into the preferences of the IMF's member states and the internal dynamics of decision-making. In order to illustrate how strategic ambiguity resulted in ineffective and inconsistent behaviour during the emerging market crises, I review the IMF's participation in exchange rate policy decisions in Mexico, Brazil, Russia and Argentina. ${ }^{1}$

\section{Organizational and PA approaches to international financial governance}

Scholars across several disciplines have developed a thriving literature that seeks to explain the behaviour of IFIs and other IOs. First, an extensive literature on the politics of IFIs examines the international and domestic political constraints imposed by member states (Wade and Veneroso, 1998; Thacker, 1999; Oatley and Yackee, 2004; Stone, 2011). Recent work in the PA framework has emphasized that IFIs have collective principals with potentially conflicting interests (Hawkins et al., 2006; Copelovitch, 2010a). For example, the IMF's major principals include wealthy European countries which collectively control about $36 \%$ of votes on the executive board, giving Europe substantial over-representation (Van Houtven, 2002). ${ }^{2}$ While some authors suggest that Europe has only recently begun to act collectively in the IFIs (Weaver, 2008; Chwieroth, 2010, p. 26), this article finds that these claims understate Europe's influence.

Second, a growing organizational literature examines the processes internal to IOs and the relationship of these organizations to their environment. Constructivist international relations scholars draw on sociological theory to argue that IFIs are relatively autonomous from the member states that created them, focusing on staff expertise, organizational culture and bureaucratic career incentives (Barnett and Finnemore, 1999; Weaver, 2008; Chwieroth, 2010; Park and Vetterlein, 2010). Work by sociologists also examines these internal processes, but has emphasized how organizations react to the diverse demands of actors in their environment (Babb, 2007, 2009; Halliday and Carruthers, 2007, 2009; Chorev, 2012). In contrast to the focus on lending volume and the scope of policy conditionality in the PA literature, organizational scholars have emphasized the role of IOs in the diffusion (Barnett and Finnemore,

1 I focus on these cases because they were seen by critics (and many internal observers) as substantial governance failures and because these countries are large and systemically important. I do not claim that these cases are representative of the Fund's role in emerging markets, but rather that these are substantively important cases that demand explanation. I assume that any substantial governance failure by a major international financial institution deserves close scrutiny.

2 Japan is also a major principal, but it does not form part of a major coalition of politically and economically inter-connected countries as does Europe. 
1999) and production (Halliday and Carruthers, 2009; Park and Vetterlein, 2010) of international policy norms.

Despite different founding assumptions, both literatures recognize that IOs have some autonomy (or 'agency slack' in PA terms). Both literatures argue that IFIs pursue policy goals shaped by professional or 'technocratic' aims and bureaucratic interests (Chwieroth, 2010; Copelovitch, 2010b), albeit with varying emphasis. Moreover, authors working in both traditions have argued that divisions among dominant member states-preference heterogeneity, in PA terminology_increase organizations' potential for autonomy (Martin, 2006; Chwieroth, 2010; Copelovitch, 2010a). Following Chwieroth (2010, pp. 30-31), I refer to organization's efforts to shape policies in directions not demanded by member states as the exercise of agenda-setting power.

However, there are limits to the ability of IFIs to exploit divisions among member states through agenda setting. Most research on preference heterogeneity among member states (particularly from a PA perspective) has focused on specific lending decisions, rather than policy norms (Copelovitch, 2010b; Stone, 2011). Thus, it remains unclear that an IFI can promote an international policy norm opposed by a substantial coalition of powerful states. While organizational scholars argue that preference heterogeneity increases the Fund's agenda-setting power, in the widely studied case of international financial liberalization, the IMF's major shareholders substantially converged on a preference for financial liberalization (Abdelal, 2009; Chwieroth, 2010). Thus, there are few studies that examine fundamental disagreement over policy norms among IFI's major member states (particularly at the IMF).

Moreover, IFIs themselves do not always have unified and coherent preferences. As noted, 'technocratic' preferences are usually traced to the professional training of the organization's staff: in the case of the IMF, the discipline of economics. However, the economics profession lacks a robust consensus in some policy areas, weakening the Fund's claim to professional authority; exchange rate policy is one such case. While researchers have begun to pay more attention to internal debate within the Fund (Chwieroth, 2010), debates over exchange rate policy were much greater than other areas such as financial liberalization (as discussed below).

Nevertheless, the fact that agenda-setting power is limited does not mean that member states' control of IFIs is complete. Rather than increasing agenda-setting power, the conflict between an IO and one or more principals may result in coordination failure. The tension between the broad goals shared by principals and agents and narrower policy disagreements creates the potential for such coordination failures: if neither principal is willing to subordinate its policy preference for the sake of broader goals, the organization may not be able to act coherently in pursuit of these objectives. Rather, the organization may act ineffectively and incoherently, pursuing policies which are inconsistent on the organization's own terms. Such behaviour results from the fact that an IO trapped between such divided principals must engage in a delicate balancing act in order to avoid direct confrontation. The next section explains why IFIs use ambiguity as a strategic resource in such conflicts.

\section{Ambiguity as organizational strategy}

When the major member states of an IO have divergent policy preferences, the organization faces a conflict with at least one principal: it cannot comply with one shareholder's preferences without confronting those of another. Recent organizational scholarship has examined the behaviours adopted by IOs when there is a conflict between organizational preferences and 
external demands. Early work identified responses ranging from passive compliance to active resistance with external demands (Oliver, 1991; Barnett and Coleman, 2005). However, this research also identified responses that are difficult to situate on the compliance-resistance spectrum. For example, Barnett and Coleman defined 'strategic social construction' as an effort to 'redefine the broader normative environment' (2005, p. 602) that is, to alter external demands themselves. This strategy has elements of both compliance and resistance. Chorev (2012) adapted these concepts by adding a second dimension to the typology: organizations may both 'comply' and 'resist' strategically, by reframing or altering the meaning of demands.

One strategy that defies the distinction between compliance and resistance is that of avoidance. Organizations, including IOs, avoid conflict with external actors through 'ceremonial conformity', or decoupling policy from practice (Meyer and Rowan, 1977; Oliver, 1991; Barnett and Coleman, 2005; Weaver, 2008). Through decoupling, an organization declares its commitment to a particular policy, but behaves inconsistently with this policy in practice. For example, Weaver (2008) describes World Bank's public commitment to good governance combined with its tolerance of corrupt practices as 'organized hypocrisy'. This resembles Chorev's notion of 'strategic compliance', though the latter emphasizes attempts to 'alter the meaning' of external demands rather than decoupling.

However, ceremonial conformity is only one means by which organizations can avoid conflict with principals. Ceremonial conformity is a strategy of concealment which decouples talk from action, policy from practice, symbol from substance. An alternative approach is to avoid confrontation by framing policies in vague and ambiguous terms. Strategic ambiguity is a form of avoidance in which an organization avoids commitment to a clear policy in the first place. Ambiguity 'allows the politically astute bureaucrat to voice general principles without making a commitment to specific (and objectionable) programs and rules', leaving options open by 'only partially or vaguely [disclosing] their intentions and plans' (Carpenter and Moore, 2007, p. 341, 345). Strategic ambiguity resembles 'robust action' (Padgett and Ansell, 1993) though, as I argue below, there are limits on the extent to which IFIs can pursue opportunistic strategies.

Previous work on IFIs has recognized the prevalence of ambiguity in international financial governance (Best, 2005). For example, as several scholars have observed, the Bretton Woods agreement itself harboured several major ambiguities, such as the meaning of the term 'fundamental disequilibrium', which specified the conditions under which countries would be allowed to adjust their exchange rates (Best, 2005 p. 1; c.f. Babb, 2007). These authors have recognized that ambiguity is a consequence of unresolved conflicts among major principals; for example, the fundamental disequilibrium clause resulted from the inability of the US and UK governments to resolve disputes at the Bretton Woods conference. However, the literature has not examined ambiguity as a deliberate organizational strategy.

In addition to developing a typology of IOs' responses to conflict, organizational scholars have also attempted to identify the conditions under which these behaviours are likely to be adopted. Organizational scholars have discussed IOs' responses to 'conflicting' or multiple demands (Oliver, 1991, p. 153; Chorev, 2012 p. 35); Weaver (2008 p. 5) argues that ceremonial conformity is a response to such conflicts. However, organizational strategies are likely to differ in two distinct cases: first, conflict among major principals, and second conflict between these principals and weaker client states or non-state stakeholders (such as civil society groups).

Strategic ambiguity is more likely than autonomous agenda setting or ceremonial conformity when an IO encounters a fundamental policy dispute among its major principals; the incentive 
towards ambiguity is greatest when the organization itself lacks a strong claim to professional consensus with which to legitimate its preferences. When principals are divided, an organization cannot 'comply' with one principal without 'resisting' another. As a result, the organization has a strong incentive to avoid conflict with powerful states by avoiding the contested issue. In contrast, ceremonial conformity is unlikely to persuade multiple principals that their (mutually contradictory) preferences have been observed. Therefore, a strategy of concealment by decoupling policy from practice is unlikely to be an effective means of avoiding conflict.

The incentive to remain ambiguous is strongest when an organization's ability to claim that professional consensus supports its preferences is weak. An organization that possesses a strong claim to professional expertise might still attempt to exploit these divisions by using its agenda-setting power, in keeping with the notion that organizations exploit divisions among principals to advance their goals (Martin, 2006; Chwieroth, 2010; Copelovitch, 2010a). However, this behaviour is much less likely to succeed when an organization's claim to professional authority is weak, for two reasons. First, the absence of professional consensus undermines the legitimacy of an organization's claim to expert authority. Second, a weak authority claim also makes it difficult for an organization to coordinate action internally; when bureaucratic actors within the organization itself hold heterogeneous views, it becomes difficult to maintain internal discipline and professional legitimacy.

However, despite the existence of a strong incentive to avoid contested issues by exercising strategic ambiguity, this strategy has important drawbacks. While strategic ambiguity resembles 'robust action', IOs cannot emulate the opportunistic political strategies of the Medici (for whom the concept of robust action was originally developed): modern demands of transparency and accountability limit the extent and duration of strategic ambiguity. Moreover, insofar as IOs are norm-producing bodies (Halliday and Carruthers, 2009; Park and Vetterlein, 2010), ambiguity puts a severe limitation on their capacity to fulfil their mandates. IOs create norms in order to legitimate their expertise; by presenting its policy prescriptions as neutral, standardized and rooted in professional consensus, the Fund seeks to reduce resistance by client countries. Ambiguous and ad hoc policy norms limit the IMF's capacity to assert its professional authority; if the Fund effectively recognizes its ignorance in a policy domain (particularly one central to its mandate), it undermines its own capacity to discipline client states. IOs are therefore likely to limit the extent to which they deliberately pursue ambiguity.

Therefore, when strategic ambiguity undermines organizational effectiveness, IFIs face pressures to clarify policy norms. Organizational leaders face both external and internal pressures to invest in a difficult effort of norm-building and persuasion. Externally, principals are aware of the costs of ambiguity and the fact that it limits organizational effectiveness, and thus the ability of the organization to achieve their broad goals. Principals view IOs as a means for forging international agreements; thus, even divided principals may demand that organizations resolve contested issues. At the same time, organizational leaders themselves may perceive opportunities to overcome these conflicts. This entails a shift in strategy from ambiguity to attempts to exercise agenda-setting power through an active effort to persuade principals. When the underlying preferences of these principals diverge, persuasion generally entails efforts to build support for compromise policies (which is easier than inducing one principal to defer to the preferences of another).

However, in the absence of the legitimacy that derives from professional consensus, such agenda-setting efforts are likely to fail. When organizational leaders seek to build compromise in the absence of a strong grounding in professional consensus, they are forced to stretch 
evidence and theory beyond what is warranted by professional knowledge. As a result, such compromise norms are likely to be ineffective and foster inconsistent behaviour by the organization. Moreover, principals can draw their own conclusions about the legitimacy of proposed compromise norms and reject them. The combination of pressure for clarity and the likelihood of rejection of proposed compromises creates the potential for a direct conflict between principals and agents. This explains an under-studied aspect of the interaction between agents and principals within IOs: principals' veto over proposed policy norms. According to the theory developed here, even when ambiguity proves to be an ineffective strategy, attempts to clarify norms by exercising agenda-setting power are likely to fail.

\section{To float or to fix?}

I begin the empirical discussion with a brief review of the context shaping developing countries' exchange rate policy decisions during the 1990s. Until the 1970s, under the Bretton Woods system, most countries adhered to 'adjustable pegs' relative to the dollar-fixed exchange rates that could be modified in cases of 'fundamental disequilibrium'. With the collapse of the Bretton Woods system in the 1970s, revisions to the IMF's Articles of Agreement gave member countries the right to choose an exchange rate regime. ${ }^{3}$ However, the Articles also require the IMF to 'exercise firm surveillance over the exchange rate policies of members, and. . .adopt specific principles for the guidance of all members with respect to these policies'. ${ }^{4}$ Thus, the Fund's mandate obligates it to develop exchange rate norms.

In practice, while the end of the Bretton Woods era saw a transition to a global monetary system based on flexible exchange rates among the major currencies, change in the developing world was slower and more uneven (Reinhart and Rogoff, 2004). The currencies of many developing countries remained pegged to the dollar well after the demise of Bretton Woods. During the 1980s and 1990s, a number of developing countries adopted 'exchange rate-based stabilization' plans: fixed exchange rates intended to control inflation. Some countries adopted 'hard pegs', such as currency boards, a form of legally fixed exchange rate reintroduced by Argentina in 1991 and subsequently emulated in several Eastern European countries.

Throughout the 1990s, policy debates continued over whether countries should float their currencies (allow them to adjust in accordance with market forces), adopt a hard peg or some intermediate regime. When John Williamson prepared the 10 points of his now-infamous Washington consensus, he included a 'competitive exchange rate' on the list (Williamson, 1989), usually implying an intermediate regime. But as Williamson himself later recognized, the claim of consensus on this point was 'wishful thinking' on his part (Williamson, 2009). Other observers have been more forceful, arguing that '[the] wildly gyrating ideas' about exchange rate regimes are 'good examples of the lack of consensus or indeed the confusion that prevailed among the experts' (Naim, 2000, p. 505).

Professional opinion on the exchange rate question reflected two competing tendencies. On the one hand, there was a broad shift in favour of flexible exchange rates beginning in the 1960s (Frankel, 1996). Surveys of the profession show that a majority of US-based economists supported floating exchange rates by the early 1990s (Alston et al., 1992), though these surveys probably reflect opinion about major currencies rather than developing countries. On the other, a

3 IMF, 'Exchange Rate Regimes in an Increasingly Integrated World Economy', SM/99/216, p. 76.

4 Articles of Agreement, Article IV, Section 3. 
significant strand of mainstream professional opinion has defended the merits of fixed exchange rates. Within modern economics, the persistence of such ideas is exemplified by Nobel prize winner Robert Mundell, an outspoken advocate of fixed rates (Mundell, 2000). Though few economists followed Mundell's strong views, many were pragmatic supporters of fixed exchange rates in developing countries (Hausmann, 1999; Calvo, 2001; Dornbusch, 2001; Fischer, 2001). These supporters included prominent international officials such as Stanley Fischer (First Deputy Managing Director of the IMF from 1994 to 2001) and Ricardo Hausmann (Chief Economist of the Inter-American Development Bank from 1994 to 2000).

As I show below, the IMF's staff generally favoured currency flexibility in developing countries. However, the Fund also became increasingly receptive to the arguments for exchange ratebased stabilization and 'hard pegs' over the course of the 1990s. On the Fund's Executive Board, European countries were the strongest defenders of fixed regimes. Although accounting for this preference is not the goal of this article, it is worth noting that Europe was in the midst of the process of monetary unification that culminated in the creation of the Euro during this period. Either because European policymakers tended to filter their views of developing countries' policy options through their own experience, or because they wanted to avoid the precedent of a policy norm that might undermine the international legitimacy of the Euro, European Directors tended to defend fixed exchange rates in developing countries.

The extent of professional debate can be assessed in comparison with another key policy area within the IMF during the 1990s: international financial liberalization. According to a large body of work (Leiteritz, 2005; Abdelal, 2009; Chwieroth, 2010; Moscella, 2012), during this period, a strong consensus emerged within the Fund in favour of financial liberalization, despite the persistence of important debates over issues of implementation. According to the IMF's Director of Research at the time, Michael Mussa, 'there was a basic consensus that in the long run a liberal financial regime. . .was the objective to aim for' (Chwieroth, 2010 , p. 155). In contrast, according to Mussa, on the exchange rate issue 'there never was an entirely consistent view, certainly within the IMF, or . . . more broadly in the economic policy community . . . there certainly were swings in the center of opinion'.5 Similarly, according to the Director of the Western Hemisphere Department, 'When we were sitting down and talking about resource allocation, relative prices. . .subsidies, differential exchange rates ${ }^{6} \ldots$ fiscal policy, banking sector management, it didn't matter where you came from . . . we all ended up with a consensus. When we talked about the exchange rates, we were all over the place'. ${ }^{7}$ This is not so say that the exchange rate debates are entirely unique; other areas of professional debate also likely existed within the Fund. Nevertheless, the exchange rate issue was an area of particularly intense debate during this period.

\section{Contested economics at the International Monetary Fund}

To identify the policy views of the IMF's principals, and to assess how the staff reacted to these heterogeneous preferences, I examine two major discussions of exchange rate policy on the

5 Interview, Michael Mussa.

6 'Differential exchange rates' refers to the practice of segmenting the exchange rate into different markets (e.g. for categories of imports and exports), which is distinct from the issue of the exchange rate regime.

7 Interview, Claudio Loser. 
IMF's Executive Board, held in 1990 and 1999. Working with transcripts obtained from the IMF's archives, I coded the position taken by the Executive Director (henceforth ED or Director) representing each country (or group of countries) ${ }^{8}$ on the issue of exchange rate policy in developing countries. In addition, I provide qualitative evidence regarding the dynamics of staff-board interaction drawn from the transcripts and accompanying documents prepared by the staff. I also interviewed former IMF staff members and other participants in these debates in order to establish the context surrounding these discussions. ${ }^{9}$

\subsection{Endorsing ambiguity: exchange rate debates in the early $1990 \mathrm{~s}$}

The Board's 1990 meeting reveals the extent to which exchange rate norms had become a source of debate within the Fund. In particular, several European Directors had become critical of the staff's perceived bias towards floating exchange rates. Staff acknowledged these debates, noting that 'several Directors have questioned the perceived readiness of the staff to recommend a flexible exchange rate policy ... [implying] that Fund policy advice has tended to favor excessive flexibility in exchange rate management'. ${ }^{10}$ The US ED was more direct, noting the history of 'heated debates' on the board. ${ }^{11}$ The German Director summed up the debate by noting that he had 'reservations with regard to the conduct of exchange rate policy... we were not convinced that a uniform policy prescription for a flexible exchange rate management lived up to the difficult circumstances' ${ }^{12}$ Likewise, the Dutch Director observed that in the past he had 'devoted attention to exchange rate policies in two-thirds of the statements on countries, almost always questioning the staff's approach'. ${ }^{13}$

An internal review confirmed European Directors' perception of staff preference for flexible exchange rates. The report coded the staff's assessment of the exchange rate regime in surveillance reports in the preceding 2 years. ${ }^{14}$ Results showed that while the staff made a 'favorable' assessment of flexible regimes in $76 \%$ of cases, the staff's view of fixed regimes was favourable in only $28 \%$ of countries. Conversely, the staff's assessment was critical in roughly $45 \%$ of countries with fixed rates, and only $24 \%$ of countries with floating rates.

Table 1 assesses the distribution of views on the Board by reporting Directors' positions on exchange rate-based stabilization. ${ }^{15}$ The Board was evenly split between strong supporters, qualified supporters and critics of use of the exchange rate as a stabilization device. A small but vocal coalition of strong supporters (including France, Italy, the Netherlands and the Scandinavian countries) advocated fixed exchange rates; for example, the French Director argued that 'the balance should be tilted, today, in favor of more stable nominal exchange

8 Only the USA, UK, Germany France, Japan and Saudi Arabia directly appoint their Executive Directors; all other countries are represented by 'elected' Directors that jointly represent groups of countries.

9 I interviewed Michael Mussa, Claudio Loser, Teresa Ter-Minassian, Guillermo Calvo, John Williamson, Anoop Singh and Karen Lissakers in Washington, DC, or by telephone.

10 IMF, 'Analytical Issues Relating to Fund Advice on Exchange Rate Policy', SM/90/198, October 16, 1990, p. 4.

11 IMF, 'Minutes of Executive Board Seminar 90/7', November 21, 1990, p. 26.

12 Ibid, pp. 17-18.

13 Ibid, p. 5.

14 IMF, 'Review of Exchange Rate Policy Assessments in Recent Article IV Consultations', SM/90/200, October 18, 1990, p. 12, 21.

15 Vote share is reported because it provides a measure of the relative influence of each group of countries in the Fund, not because decisions were put to a direct vote. 
Table 1. IMF executive directors' positions on exchange rates-based stabilization, 1990

\begin{tabular}{lllll}
\hline & Strong support & Qualified support & Critical & Undetermined \\
\hline \% of board & $22.7 \%$ & $27.3 \%$ & $22.7 \%$ & $31.8 \%$ \\
\% of vote & $19.4 \%$ & $23.6 \%$ & $37.4 \%$ & $20.9 \%$ \\
Countries & France & Germany & USA & Indonesia \\
& Italy & Belgium & UK & Uruguay \\
& The Netherlands & Spain & Japan & Iran \\
& Norway & Saudi Arabia & Canada & Pakistan \\
& Burkina Faso & Chile & India & Australia \\
& & Zambia & & China \\
& & & Brazil \\
\hline
\end{tabular}

rate commitments'. ${ }^{16}$ Similarly, the Italian Director argued that 'fixed but revocable exchange rate rules [i.e. adjustable pegs] are desirable for countries undertaking adjustment programs, and their adoption should be encouraged - a point which I support more strongly than does the staff'. ${ }^{17}$ Qualified supporters (such as Germany and Belgium) were more circumspect, recognizing the limits of this strategy, but also supporting the policy on balance. ${ }^{18}$ Critics (including the USA, UK and Japan) argued that developing countries should be discouraged from relying on the exchange rate for stabilization purposes, arguing that most developing countries should pursue currency flexibility. Thus, a sizable coalition representing $43 \%$ of votes (and $50 \%$ of Board members), including most of Europe, were either strong or moderate supporters of exchange rate-based stabilization, while critical members accounted for only $37 \%$ of votes.

In response to this preference heterogeneity, the staff formulated an ambiguous position that endorsed an ad hoc, case-by-case approach rather than formulate a clear policy norm. The staff carefully hedged its views by noting that the appropriate exchange rate regime '[depends] crucially on the specific circumstances faced by individual countries'. ${ }^{19}$ The report concluded with the ambiguous and ambivalent recognition that a wide range of regimes were sustainable under diverse circumstances, without clearly specifying what those circumstances were. The strongest preference expressed by the staff was for intermediate regimes, and staff did take a step towards advocating flexibility by arguing that some exchange rate adjustment was inevitable for countries facing balance of payments crises. However, the staff's defence of this preference was ambivalent, acknowledging that in countries attempting to stabilize high inflation, commitment to 'fix the exchange rate for an extended period would help provide a strong anchor for price stability'. ${ }^{20}$ Staff did not carefully stipulate the conditions under which fixed exchange rate plans were likely to be sustainable or consider the difficult process of 'exiting' a fixed exchange rate. Rather than exercise its obligation to exercise 'firm surveillance', the staff failed to formulate a clear policy norm.

16 IMF, 'Minutes of Executive Board Seminar 90/7', p. 32.

17 Ibid, p. 42.

18 I code the German position as 'qualified support' because of the Director's reference to previous disagreements with the staff and the comment 'a stable exchange rate policy can play an important role as an explicit tool in supporting a country's stabilization effort'. However, the differences between the USA and Germany were a matter of degree.

19 IMF, 'Analytical Issues', pp. 1-2.

20 IMF, 'Analytical Issues', p. 35. 
The staff's strategic avoidance of the exchange rate question reflected deep professional uncertainty as well as the divisions among member states. The staff felt compelled to emphasize that 'economic research has not reached a consensus' on many of the relevant relationships and that the criteria discussed in the theoretical literature were 'difficult to apply . . . to specific cases' ${ }^{21}$ This professional uncertainty hindered the ability of the staff to make a strong claim to professional authority in favour of their generally pro-flexibility views. Directors emphasized that economic theory provided little guidance; the US ED stated that 'neither economic theory nor practical experience offers any hard and fast rules' (a point echoed by Japan). ${ }^{22}$ Thus, the Fund's principals were well aware of the limits of economic theory and research, which limited the extent to which the staff could claim that professional consensus supported its views.

Given the limits of professional knowledge, it might be argued that the staff's ambiguity was not strategic, but simply the reflected the inherent indeterminacy of exchange rate policy. However, several considerations suggest that the staff softened its position in an effort to avoid conflict with its principals. First, that the staff's position was deliberately accommodating is suggested by the shift in the position of the German Director, who had 'expressed reservations about the staff's views' in the past but now stated that he 'fully [agreed] with the staff when it stresses . . there are no easy answers to the choice of the optimal exchange rate regime'. ${ }^{23}$ In other words, the staff won German support largely by taking an ambiguous and ad hoc position. Second, some IMF staff members were themselves 'deeply unsatisfied'; Research Director Mussa colourfully described the 'firm surveillance' demanded by the Articles of Agreement as 'about as firm as an overripe avocado-without the pit' (Mussa, 2007). Third, Mussa himself described a 'pact of mutual non-aggression among the members of the Executive Board' (ibid) which motivated staff ambiguity on the exchange rate issue.

The staff's strategic ambiguity was not limited to abstract policy debates, but was also apparent in its interaction with client countries, particularly during several high-profile crises. For example, in Mexico, despite important warnings from independent economists over the sustainability of the exchange rate-based stabilization plan (Dornbusch and Werner, 1994) and the contention of the US Director that 'some depreciation of the peso may be in order', ${ }^{24}$ the final staff report prior to the crisis offered at best the tepid claim that 'the authorities will need to continue to keep exchange rate developments under review'. ${ }^{25}$ A highly critical internal report following the crisis observed that the staff had concealed its diagnosis in obscure language (Boughton, 2012, p. 113). In the case of Brazil, the Fund was more proactive; staff diagnosed a significant overvaluation of the currency relatively early and advised the Brazilian government to change policies. Nevertheless, the staff gave in 'quickly but reluctantly' in face of resistance from the Brazilian government to a change in policy (Boughton, 2012, p. 559).

There is substantial evidence that European support for fixed exchange rate regimes prevented the IMF staff from a more forceful advocacy of exchange rate flexibility. In a Board discussion less than a year before the crash, despite the concern of the US representative and staff, the Italian Director 'embodied the majority in concluding that "the conditions

21 IMF, 'Analytical Issues', p. 1, 13.

22 IMF, 'Minutes of Executive Board Seminar 90/7', p. 29.

23 Ibid, p. 17.

24 See IMF, 'Mexico-Staff Report for the 1993 Article IV Consultation', SM/94/31, February 1, 1994.

25 Ibid, p. 12. 
seem to be in place now for a successful hardening of the exchange rate commitment", (Boughton, 2012, p. 458). In Brazil, the national authorities' resistance to depreciation was supported by a substantial coalition of 'major shareholders' (Independent Evaluation Office, 2003, p. 23). The US Executive Director later observed that 'the [IMF] Board had been thoroughly implicated in the decisions to support . . . the Brazilian peg', ${ }^{26}$ implicitly referring to European Directors (since the USA itself had not been a supporter).

The weaknesses of IMF governance in this area underscore the limits of strategic ambiguity in IOs. The failure to formulate a clear exchange rate policy norm weakened the Fund's ability to diagnose and act on exchange rate misalignments, such as the overvaluation of the Mexican and Brazilian currencies. Despite evidence of substantial staff concern over the sustainability of these currency regimes, the absence of a formal fund policy made it difficult for the IMF staff to take a clear and assertive position in these countries. This was the clearest in the Brazilian case, where the staff had raised clear alarms about the currency regime but quickly backed down. Within the IMF itself, the Fund's role in these crises was seen as a major failure of 'surveillance', as reflected in a series of internal diagnostic reports, such as the report on the Mexican crisis mentioned above and the later reports of the Independent Evaluation Office (IMF, 2003, 2004, 2007).

The IMF's strategic ambiguity on the exchange rate issue and its passivity in Mexico and Brazil reflect a coordination failure in which debate over exchange rate policy prevented the USA, European governments and the IMF itself from acting coherently in pursuit of their overarching goal of maintaining the stability of the global monetary system. Despite the fact that both the US government and the Fund's staff were concerned about the implications of exchange rate-based stabilization, both in general and in particular countries, the IMF took no strong action and provided ambiguous policy advice in several important cases. Stalemate over the exchange rate issue prevented the Fund from adopting any clear policy, and the ineffective and inconsistent behaviour that resulted was perceived within the Fund itself as an important governance failure.

\subsection{Seeking clarity: the failed institutionalization of the bipolar view}

The weaknesses of IMF governance imposed by ambiguous exchange rate policy norms discussed in the previous section generated substantial internal and external pressure for clarity. Even before the crisis in Mexico, staff was uncomfortable with ambiguity. As noted above, Research Director Michael Mussa, who joined the Fund in 1991, was dissatisfied with the organization's ambiguous stance and began an initiative to 'reinvigorate IMF exchange rate surveillance' (Michael Mussa, 2007). The 1992 crisis of the European Monetary System (EMS), though the Fund was not directly involved, increased concern about the sustainability of the 'intermediate' fixed exchange regimes implemented by many of the Fund's clients. These concerns intensified in the wake of the Mexican crisis; the internal report mentioned above found that the staff's oversight of Mexico was ineffective and had given excessive 'benefit of the doubt' to the national authorities (Boughton, 2012, p. 113). This internal criticism created a significant impetus to clarify global exchange rate norms, which intensified further following the East Asian and Russian crises.

The positions taken by staff in the course of seeking clarity reflected two somewhat contradictory tendencies in the evolution of professional opinion on exchange rate issue. On the one 
hand, staff research reached the conclusion that exchange rate-based stabilization was effective at ending high inflation (Végh, 1992; Calvo and Végh, 1994). On the other hand, Fund staff and other macroeconomists interpreted the EMS and Mexican crises as showing that intermediate fixed regimes were inherently vulnerable in a world of rapid capital flows. While some interpreted this as a rationale for flexibility, others argued that countries should strengthen their commitment to fixed exchange rates by adopting 'hard pegs'. Staff opinion on hard pegs gradually changed; while the Fund was sceptical of 'currency boards' such as the Argentine system in the early 1990s (Cavallo and Cottani, 1997), views began to shift after Argentina defied predictions of collapse during financial contagion following the Mexican crisis. ${ }^{27}$ Despite continued internal debates, the Fund began to endorse currency boards and even recommend their adoption in a few cases, as we see below.

An important source of support for exchange rate-based stabilization and hard pegs came with the appointment of Stanley Fischer to the position of First Deputy Managing Director, the Fund's second-highest position, in 1994. Fischer's views had evolved over his career towards endorsing exchange rate-based stabilization and 'hard pegs' such as currency boards. ${ }^{28}$ Under Fischer's leadership, during the late 1990s. the IMF began to formulate a compromise norm, the so-called bipolar view, which aimed to satisfy both supporters of currency flexibility and proponents of exchange rate-based stabilization. The norm held that 'emerging market' countries must choose between 'hard pegs' and freely floating currencies-but that intermediate regimes were unsustainable (Fischer, 2001). ${ }^{29}$ This represented a major reversal of the staff's position in favour of intermediate regimes and a much more constrained view of developing countries' policy options than that prevailing at the beginning of the 1990s.

The bipolar view was a nuanced but consistent norm; it represented a determined effort by the Fund's senior leadership to clarify the Fund's position on exchange rate regimes. However, it was also a strained attempt to reach compromise both among the Fund's major principals and within the economics profession itself. The bipolar view was not the result of the emergence of a robust consensus in the economics discipline, or within the Fund; interviews with former IMF staff members confirmed that the bipolar view was Fischer's personal initiative. ${ }^{30}$ With the benefit of hindsight, there are two ways in which the bipolar view proved ineffective as a norm for governing the international monetary system. First, the norm placed excessive confidence in the sustainability of 'hard pegs'; this confidence rested (particularly for large 'emerging market' countries) almost entirely on the Argentine currency board; after the collapse of the Argentine regime, the case for hard pegs appeared substantially weaker (Edwards, 2002). Second, the rejection of 'intermediate' regimes under the bipolar view was in part an empirical generalization that proved to be an artefact of inadequate data (Reinhart and Rogoff, 2004). Following the Argentine crisis (and Fischer's departure), the bipolar view quietly disappeared from IMF rhetoric.

The bipolar view's embrace of 'hard pegs' also resulted in ineffective and sometimes incoherent behaviour by the Fund. During the latter half of the 1990s, the Fund recommended adoption of currency boards in several countries, including Bulgaria, Russia and Brazil (Boughton, 2012, p. 282, 338, 604). In both Russia and Brazil, the Fund had supported persistence with exchange

27 Interview, Michael Mussa.

28 Mussa interview; see also Fischer (2004, ch. 11; 2001).

29 This claim was later qualified as specific to emerging markets (countries deeply involved in global capital markets), but was initially framed more broadly (see Fischer, 2001, p. 5).

30 Interviews, Claudio Loser and Michael Mussa. 
rate-based stabilization despite concerns about its sustainability; then, after these countries' currency regimes collapsed, the Fund redoubled its bet on fixed rates by recommending a hard peg. This recommendation was hard to justify on macroeconomic grounds and, given the reluctance of the national authorities to adopt an extreme and relatively untested currency regime, was ignored by the national authorities. In the Russian case, the Fund's behaviour was glaringly inconsistent-Managing Director Michel Camdessus advised the authorities to adopt a currency board even as the staff was recommending a floating currency (Boughton, 2012, p. 338)—a rare lapse for a highly disciplined organization. The Fund also behaved inconsistently by opposing currency boards in some countries (such as Indonesia) while recommending them in others; while arguments could be presented about why a hard peg was appropriate in one case but not in another, in the light of the generally untested character of currency boards, such arguments were weakly grounded in evidence.

Similarly, the bipolar view committed the Fund to support for the Argentine currency system at a time when, as ex post accounts of the crisis have argued, the Argentine authorities could have most effectively implemented an 'exit strategy' to a more flexible regime (Mussa, 2002; Independent Evaluation Office, 2004). Following its initial scepticism, the Fund 'moved towards a more explicit stance in support of the exchange rate peg'; this occurred despite persistent internal debates, such as a 1996 Fund report which 'questioned the appropriateness of the exchange rate arrangement' (Independent Evaluation Office, 2004, pp. 19-20). Thus, the Fund behaved inconsistently, identifying significant policy problems internally but failing to raise them externally.

In the wake of the East Asian and Russian crises, internal impetus for clarity was intensified by substantial external pressure for reform. High-level ministerial working groups created in response to the crisis cited exchange rate regimes as an area of global monetary governance needing reform. ${ }^{31}$ This task was delegated to the IMF in 1999 with a directive from the Interim Committee-essentially a meeting of the Fund's major principals-to 'consider further the issue of appropriate exchange rate arrangements, including in the context of large-scale official financing. ${ }^{32}$ This injunction amounted to a direct appeal from the Fund's principals for normative clarity with regard to exchange rate regimes. In the oblique language of international financial governance, the directive also implied that the Fund should decide whether to alter its deference towards national exchange rate policy choices and cut off funding to countries deemed to be implementing unacceptable policies. In the context of the Fund's shift towards the bipolar view, this implied withdrawing support for intermediate regimes.

In response to both internal and external pressure for reform, the staff produced a report that broadly endorsed the bipolar view. ${ }^{33}$ This report represented a substantial effort to persuade divided principals to agree on a compromise position. However, while the bipolar view had the support of top management, it faced resistance on the Executive Board. As Table 2 shows, only four countries (the USA, Canada, Poland and Chile) supported the bipolar view at a 1999 meeting convened to discuss the report. Other countries rejected the bipolar view,

31 Report of the Working Group on International Financial crises' (G-22, 10/1998), available at http://www. imf.org/external/np/g22/ifcrep.pdf; 'Communiqué of G-7 Finance Ministers and Central Bank Governors', February 20, 1999. Available at http://www.g8.utoronto.ca/finance/fm022099.htm.

32 IMF Press Release 99/15, 'Communiqué of the Interim Committee of the Board of Governors of the International Monetary Fund'.

33 IMF, 'Exchange Rate Regimes in an Increasingly Integrated World Economy', SM/99/216. 
Table 2. IMF executive directors positions on bipolar view, 1999

\begin{tabular}{llllll}
\hline & Bipolar & Support fixed & Support intermediate & Support float & Undetermined \\
\hline \% of board & $16.7 \%$ & $16.7 \%$ & $37.5 \%$ & $12.5 \%$ & $16.7 \%$ \\
\% of vote & $26.0 \%$ & $14.3 \%$ & $34.2 \%$ & $15.0 \%$ & $10.4 \%$ \\
Countries & USA & France & UK & Germany & Brazil \\
& Canada & Denmark & Japan & Austria & Saudi Arabia \\
& Poland & Thailand & Russia & Mexico & New Zealand \\
& Chile & Iran & India & & Djibouti \\
& & Ukraine & & \\
& & China & & \\
& & Greece & & \\
& & Angola & & \\
& & Egypt & & \\
\hline
\end{tabular}

though for different reasons. Some-representing roughly $16 \%$ of the vote share, including France and the Scandinavian constituency represented by Denmark, returned to arguments raised at the beginning of the decade in favour of exchange rate-based stabilization. The Danish Director, for example, insisted the 'the Fund should not issue a blanket warning against fixed exchange rate policy'. ${ }^{34}$ The largest group of countries resisted the bipolar view's rejection of 'intermediate' regimes, while Germany had shifted its position towards support for floating currencies but questioned the case for hard pegs. Given this preference heterogeneity, the Executive Board's first meeting ended in stalemate.

However, in contrast to the early 1990s, the staff now invested much greater effort in using its agenda-setting power to clarify policy norms. Less than 2 months after the first 1999 meeting, the staff asked the Board to reconsider the issue, provoking perplexity and frustration among Directors. Staff attempted to resolve the inconclusive debate of the previous discussion by framing the issue in three direct questions which essentially asked the Board to support the bipolar view. ${ }^{35}$ However, the staff's insistence on institutionalizing the bipolar view provoked a strong reaction from the Board. The Australian Director proclaimed that he was 'surprised to see this topic back before the Board quite so soon', a complaint echoed by Directors from Germany, the UK, Austria, Switzerland and Greece. ${ }^{36}$ The French Director declared himself 'uncomfortable with the way that [the] options for discussion are presented today', ${ }^{37}$ in particular the staff's presentation of the policy choices as a stark float-or-fix dichotomy. Directors from Germany, Japan, Austria, Brazil and Greece explicitly seconded the strongly worded French position. The Austrian director observed that opposition to the bipolar view hardened, noting that 'today's discussion forced almost all Directors to speak out against a biased approach' ${ }^{38}$ Explicit opposition from a coalition of principals, primarily European, amounted to a veto of the bipolar view as Fund policy.

34 IMF, 'Minutes of Executive Board Meeting 99/107', EBM/99/107, September 21, 1999, p. 22.

35 IMF, 'Minutes of Executive Board Meeting 99/125', EBM/99/125, November 15, 1999, pp. 4-5.

36 Ibid, p. 14.

37 Ibid, p. 9.

38 Ibid, p. 33. 
The ineffectiveness of this global policy norm is also reflected in the lukewarm support of the US Director for the bipolar view. The USA had taken a sceptical position on hard pegs; at a seminar on currency boards 2 years earlier, the US Director maintained that this policy should be used only as a temporary transitional policy 'in very limited circumstances' and with welldefined exit strategies. ${ }^{39}$ This position was substantially at odds with the bipolar view, which held that currency boards were sustainable in the long run. At the 1999 meeting, the US Director argued that the staff had been far too generous in conceding the benefits of hard pegs, arguing that 'the Fund should establish a clear presumption for emerging markets that flexible exchange rates are the strongly preferred course'. ${ }^{40}$ Thus, while the USA was willing to endorse the bipolar view in principal, its lack of enthusiasm for hard pegs undermined its basic message.

Thus, the bipolar view resulted in effective and incoherent governance and failed to generate consensus because it pleased neither the US nor European principals, for opposing reasons. The IMF's advocacy of the bipolar view - and the endorsement of 'hard pegs' this entailed-committed the Fund to endorsing regimes such as the Argentine currency board which, as the organization's own ex post analysis found, should have been abandoned earlier. The IMF also behaved incoherently (for example, by giving contradictory advice to Russia) and ineffectively (by giving advice to Brazil which was simply ignored and, if adopted, would likely have been catastrophic, given the Argentine cataclysm). At the same time, the bipolar view brought staff and management into direct conflict with a coalition of European principals, who effectively vetoed the policy norm. Rather than create an opportunity for the Fund to exercise its agenda-setting power, building consensus around a compromise position, the staff's attempt to force the issue escalated conflict within the Fund and culminated in an explicit European veto. The result was a coordination failure in which US and European principals, and the organization itself, failed to act coherently in pursuit of their shared objective of international monetary stability.

\section{Conclusions}

This article has described an organizational behaviour-strategic ambiguity—which has not received sustained attention in previous work on IFIs or IOs more generally. Empirically, I find that the IMF avoided formulating clear exchange rate policy norms - despite its mandate to provide 'firm surveillance' over these policies and the centrality of this issue to its mandate-by adopting a posture of strategic ambiguity. While this minimized conflict in the short run, it prevented the IMF from exercising an effective governance role in client countries where the exchange rate became a critical issue, including Mexico, Russia, Brazil and Argentina. Though the Fund recognized concerns about the sustainability of these countries' currency regimes, it either failed to act (as in Mexico) or capitulated to client countries and European principals (in Brazil). Late in the decade, in part because of these failures, the IMF's leadership attempted to clarify policy norms by promoting the bipolar view. However, this compromise norm was weakly grounded in professional consensus and resulted in ineffective and sometimes incoherent behaviour. Moreover, the norm failed to placate divided principals and was ultimately vetoed.

39 'Statement by Ms Lissakers and Mr Sobel on Currency Board Arrangements-Issues, Experiences and Implications for Fund-Supported Programs (Preliminary)', Executive Board Seminar 97/1, January 22, 1997 (Gray/97/17).

40 IMF, 'Minutes of Executive Board Meeting 99/125', EBM/99/125, November 15, 1999, p. 55. 
One limitation of study of a single policy area is that, because this policy domain was characterized by both divided principals and professional debate, it is not possible to isolate the influence of these factors. While I have proposed that professional debate intensifies the incentive to adopt strategic ambiguity, this argument cannot be strictly tested in this article, which has focused on building theory. Future studies should examine policy areas in which either divergent preferences among principals or professional consensus (but not both) are present. Promising area for further research includes the IMF's evolving positions on sovereign debt restructuring, counter-cyclical fiscal policy (Ban, 2015), capital controls (Grabel, 2011) and bank regulation (Gabor, 2015).

For example, in 2001, IMF managers proposed the creation of a sovereign debt restructuring mechanism (SDRM), a kind of international bankruptcy court for government debtors. This proposal was rapidly vetoed by the USA. The ability of the USA to block a policy it opposed reflects the power of the Fund's major principal, but the fact that the proposal occurred at all reflects the Fund management's effort to set the policy agenda. Moreover, the Fund's agenda setting did not end with the US veto, but has taken on new energy in the ongoing Eurozone crisis, particularly in Greece. In this case, there is some evidence of direct conflict between a substantial coalition of European creditor states (particularly Germany) and the IMF on the issue of whether the Greek debt burden is ultimately payable. On the face of it, this conflict appears to reflect a substantially greater agenda-setting effort on the part of the IMF; on the argument presented here, direct confrontation between both the USA (over the SDRM proposal) and Germany (over Greece) would imply that Fund officials believed that they had a stronger professional warrant to pursue these policy goals, resulting in less ambiguity. However, conflict also occurred in the exchange rate case (for example, over the bipolar view); thus, conflict per se is not a reliable indicator of the absence of strategic ambiguity. Only a careful study of the IMF's behaviour over a long period can fully account for organizational strategies and their determinants in this policy domain.

Another interesting case is the recent shift in the Fund's position on counter-cyclical fiscal policy and fiscal multipliers. In the wake of the 'great recession', IMF research increasingly recognizes that fiscal multiplier are 'high', implying that austerity undermines growth and Keynesian-style deficit spending programmes are often appropriate. This again brings the IMF into potential conflict with major principals, including Germany and the UK. While the existence of large positive fiscal multipliers is not universally accepted in the economics profession, a sizable coalition of mainstream economists makes a strong claim to professional certainty on this point; thus, the IMF staff appears to believe that it has a strong professional warrant. In this case, in the presence of greater professional certainty, the Fund's behaviour appears less strategically ambiguous. However, as with the sovereign debt policy area, observation of IMF behaviour over a longer time period is required to assess the extent of strategic ambiguity.

Notwithstanding its focus on a single policy area, this article has several important implications for future research on the IMF and other IFIs. First, researchers should be more attentive to strategic ambiguity as a means to avoid conflict and the contexts in which it is adopted. Second, researchers need to study situations in which major principals have genuinely divergent policy preferences. Claims about the Fund's ability to autonomously set the policy agenda in the area of international financial liberalization are limited by the fact that shareholders' preferences were largely aligned on this issue, at least during the period of the 1990s which 
has been studied most extensively. When principals' policy preferences truly diverged, the IMF was reluctant to risk confrontation with powerful states. A corollary is that research needs to take the power of major principals other than the USA, particularly European countries, more seriously. This article has shown that European principals can veto a policy norm that they do not support. Finally, research should also examine policy areas in which the IMF has a weak claim to professional authority; these include issues just mentioned, such as sovereign debt management and international banking regulation, which have gained prominence since the global financial crisis. If the theoretical claims of this article prove to be generalizable, researchers will uncover further instances of strategic ambiguity when professional uncertainty coincides with divided principals, but may encounter more autonomy when IFIs have a stronger claim to professional consensus.

\section{Acknowledgements}

I thank Erik Olin Wright, Joseph Harris, Terrence Halliday, Jens Bekert and audiences at the American Sociological Association and the University of Edinburgh for comments on previous versions of this paper.

\section{Funding}

Research for this paper was supported by the Social Science Research Council, the National Science Foundation (award number SES-0957298) and the Robert F. and Jean E. Holtz Center at the University of Wisconsin-Madison.

\section{References}

Abdelal, R. (2009) Capital Rules: The Construction of Global Finance, Cambridge, Harvard University Press.

Alston, R. M., Kearl, J. R. and Vaughan, M. B. (1992) 'Is There a Consensus among Economists in the 1990s?', American Economic Review, 82, 203-209.

Babb, S. (2007) 'Embeddedness, Inflation, and International Regimes: The IMF in the Early Postwar Period', American Journal of Sociology, 113, 128-164.

Babb, S. (2009) Behind the Development Banks: Washington Politics, World Poverty and the Wealth of Nations, Chicago, University of Chicago Press.

Ban, C. (2015) 'Austerity versus Stimulus? Understanding Fiscal Policy Change at the International Monetary Fund Since the Great Recession', Governance, 28, 167-183.

Barnett, M. and Coleman, L. (2005) 'Designing Police: Interpol and the Study of Change in International Organizations', International Studies Quarterly, 49, 593-619.

Barnett, M. and Finnemore, M. (1999) 'The Politics, Power, and Pathologies of International Organizations', International Organization, 53, 699-732.

Best, J. (2005) The Limits of Transparency: Ambiguity and the History of International Finance, Ithaca, Cornell University Press.

Boughton, J. M. (2012) Tearing Down Walls: The International Monetary Fund 1990-1999, Washington, DC, International Monetary Fund.

Calvo, G. (2001) 'The Case for Hard Pegs in the Brave New World of Global Finance'. In de Macedo, J. B., Cohen, D. and Reisen, H. (eds) Don't Fix, Don't Float: The Exchange Rate in Emerging Markets, Transition Economies and Developing Countries, Paris, OECD Development Center, pp. 77-84. 
Calvo, G. and Végh, C. (1994) 'Inflation Stabilization and Nominal Anchors', Contemporary Economic Policy, 12, 35-45.

Carpenter, D. and Moore, C. D. (2007) 'Robust Action and the Strategic Use of Ambiguity in a Bureaucratic Cohort: FDA Scientists and the Investigational New Drug Regulations of 1963'. In Glassman, M. and Skowronek, S. (eds) Formative Acts: American Politics in the Making, Philadelphia, University of Pennsylvania Press, pp. 340-362.

Cavallo, D. and Cottani, J. (1997) 'Argentina's Convertibility Plan and the IMF', American Economic Review, 87, 17-22.

Chorev, N. (2012) The World Health Organization between North and South, Ithaca, Cornell University Press.

Chwieroth, J. M. (2010) Capital Ideas: The IMF and the Rise of Financial Liberalization, Princeton, Princeton University Press.

Copelovitch, M. S. (2010a) 'Master or Servant? Common Agency and the Political Economy of IMF Lending', International Studies Quarterly, 54, 49-77.

Copelovitch, M. S. (2010b) The International Monetary Fund in the Global Economy: Banks, Bonds and Bailouts, Cambridge, Cambridge University Press.

Dornbusch, R. (2001) 'Fewer Monies, Better Monies', American Economic Review, 91, 238-242.

Dornbusch, R. and Werner, A. (1994) 'Mexico: Stabilization, Reform and No Growth', Brookings Papers on Economic Activity, 1994, 253-315.

Edwards, S. (2002) 'The Great Exchange Rate Debate after Argentina', NBER Working Paper.

Fischer, S. (2001) 'Exchange Rate Regimes: Is the Bipolar View Correct', Journal of Economic Perspectives, 15, 3-24.

Fischer, S. (2004) IMF Essays from a Time of Crisis: The International Financial System, Stabilization and Development, Cambridge, MIT Press.

Frankel, J. A. (1996) 'Recent Exchange-Rate Experience and Proposals for Reform', American Economic Review, 86, 153-158.

Gabor, D. (2015) 'The IMF's Rethink of Global Banks: Critical in Theory, Orthodox in Practice', Governance, 28, 199-218.

Grabel, I. (2011) 'Not Your Grandfather's IMF: Global Crisis, "Productive Incoherence" and Developmental Policy Space', Cambridge Journal of Economics, 35, 805-830.

Halliday, T. C. and Carruthers, B. G. (2007) 'The Recursivity of Law: Global Norm Making and National Lawmaking in the Globalization of Corporate Insolvency Regimes', American Journal of Sociology, 112, 1135-1202.

Halliday, T. C. and Carruthers, B. G. (2009) Bankrupt: Global Lawmaking and Systemic Financial Crisis, Stanford, Stanford University Press.

Hausmann, R. (1999) 'Should There Be Five Currencies or One Hundred and Five', Foreign Policy, $116,65-79$.

Hawkins, D. G., Lake, D. A., Nielson, D. L. and Tierney, M. J. (2006) Delegation under Anarchy: States, International Organizations, and Principal-Agent Theory, Cambridge, Cambridge University Press.

Independent Evaluation Office (2003) The IMF and Recent Capital Account Crises: Indonesia, Korea, Brazil, Washington, DC, International Monetary Fund.

Independent Evaluation Office (2004) The IMF and Argentina, 1991-2001, Washington, DC, International Monetary Fund.

Independent Evaluation Office (2007) IMF Exchange Rate Policy Advice, Washington, DC, International Monetary Fund.

Leiteritz, R. J. (2005) 'Explaining Organizational Outcomes: The International Monetary Fund and Capital Account Liberalization', Journal of International Relations and Development, 8, 1-26.

Martin, L. (2006) 'Distribution, Information, and Delegation to International Organizations: The Case of IMF Conditionality'. In Hawkins, D. G., Lake, D. A., Nielson, D. L. and Tierney, M. J. 
(eds) Delegation and Agency in International Organizations, Cambridge, Cambridge University Press, pp. 140-164.

Meyer, J. W. and Rowan, B. (1977) 'Institutionalized Organizations: Formal Structure as Myth and Ceremony', American Journal of Sociology, 83, 340.

Moscella, M. (2012) 'Seeing Like the IMF on Capital Account Liberalization', New Political Economy, 17, 60-76.

Mundell, R. A. (2000) 'A Reconsideration of the Twentieth Century', American Economic Review, 90, 327-340.

Mussa, M. (2007) 'IMF Surveillance over China's Exchange Rate Policy'. In Paper Presented at the Conference on China's Exchange Rate Policy, Peterson Institute.

Mussa, M. L. (2002) Argentina and the Fund: From Triumph to Tragedy, Washington, DC, Peterson Institute for International Economics.

Naim, M. (2000) 'Fads and Fashions in Economic Reforms: Washington consensus or Washington confusion?', Third World Quarterly, 29, 505-528.

Oatley, T. and Yackee, J. (2004) 'American Interests and IMF Lending', International Politics, 41, 415-429.

Oliver, C. (1991) 'Strategic Responses to Institutional Processes', Academy of Management Review, $16,145-179$.

Padgett, J. F. and Ansell, C. K. (1993) 'Robust Action and the Rise of the Medici, 1400-1434', American Journal of Sociology, 98, 1259-1319.

Park, S. and Vetterlein, A. (2010) Owning Development: Creating Policy Norms in the IMF and the World Bank, Cambridge, Cambridge University Press.

Reinhart, C. M. and Rogoff, K. S. (2004) 'The Modern History of Exchange Rate Arrangements: A Reinterpretation', Quarterly Journal of Economics, 119, 1-48.

Stiglitz, J. (2003) Globalization and Its Discontents, New York, W.W. Norton.

Stone, R. (2011) Controlling Institutions: International Organizations and the Global Economy, Cambridge, Cambridge University Press.

Thacker, S. C. (1999) 'The High Politics of IMF Lending', World Politics, 52, 38-75.

Van Houtven, L. (2002) Governance of the IMF: Decision Making, Institutional Oversight, Transparency and Accountability. Pamphlet Series No. 52. Washington, DC, International Monetary Fund.

Végh, C. (1992) 'Stopping High Inflation: An Analytical Overview', IMF Staff Papers, 39, 626-695.

Wade, R. and Veneroso, F. (1998) 'The Asian Crisis: The High Debt Model versus the Wall Street-Treasury-IMF Complex', New Left Review, 228, 3-22.

Weaver, C. (2008) Hypocrisy Trap: The World Bank and the Poverty of Reform, Princeton, Princeton University Press.

Williamson, J. (1989) 'What Washington Means by Policy Reform'. In Williamson, J. (ed) Latin American Adjustment: How Much Has Happened, Washington, Peterson Institute for International Economics, pp. 7-20.

Williamson, J. (2009) 'A Short History of the Washington Consensus', Law and Business Review of the Americas, 15, 7-23. 